\title{
Development and Validation of Nomograms for Predicting Survival of Elderly Patients with Stage I Small-Cell Lung Cancer
}

\section{Yaji Yang}

Chongqing Medical University

\section{Shusen Sun}

Western New England College: Western New England University

\section{Feng Xiong}

Chongqing Medical University

Yin Xiao

Chongqing Medical University

Jing Huang ( $\nabla 1057588658 @ q q . c o m$ )

Chongqing Medical University

\section{Research}

Keywords: Nomogram, Small-cell lung cancer, SEER, Stage I, Elderly,.

Posted Date: November 10th, 2020

DOI: https://doi.org/10.21203/rs.3.rs-103097/v1

License: (c) (i) This work is licensed under a Creative Commons Attribution 4.0 International License. Read Full License 


\section{Abstract}

Background There is a lack of predictive models to determine the prognosis of elderly patients diagnosed with Stage I small-cell lung cancer (SCLC). The purpose of this study was to establish a useful nomogram to predict the cancer-specific survival (CSS) in this patient population.

Methods Based on the Surveillance, Epidemiology, and End Results registry database, patients aged $\geq 65$ years with pathological AJCC (American Joint Committee on Cancer) Stage I SCLC from 2004 to 2014 were identified. The CSS was evaluated by the Kaplan-Meier method. Patients were randomly split into training and validation sets. In the training cohort, univariate analysis and multivariate analysis by using the Cox regression identified risk factors that affected CSS, and the results were utilized to construct a nomogram for prediction of the 1-, 3-, and 5-year CSS rates of elderly patients with Stage I SCLC. The effectiveness of the nomogram was validated internally and externally by the bootstrap method.

Results In total, we extracted 1,623 elderly patients with Stage I SCLC. The median CSS was 34 months, and the 5-year CSS was 41 months. Multivariate analysis revealed that histologic type, tumor size, age, and AJCC Stage were significant predictors of CSS. A nomogram was constructed according to the results of multivariate $\mathrm{COX}$ analysis. The $\mathrm{C}$-indices of the nomogram for training and validation sets were 0.68 and 0.62 , indicating that the nomogram demonstrated a favorable level of discrimination. The calibration curves exhibited satisfactory agreement between the actual observation and nomogram prediction.

Conclusion A practical nomogram to predict the CSS of elderly patients with Stage I SCLC is constructed. The predictive tool is helpful for patients counseling and treatment decision making.

\section{Background}

Lung cancer is one of the most common forms of cancer, and it is the leading cause of cancer mortality globally.[1] Small-cell lung cancer (SCLC) is the most aggressive type of lung cancer, characterized by paraneoplastic endocrinopathy, high cellular proliferation, and early metastatic spread.[2] With an aging population, the number of elderly individuals with lung cancer is expected to increase in the near future. More than that, growing patients are diagnosed at an earlier stage with widespread low-dose and thin-slice computed tomography screening.[3]

The National Comprehensive Cancer Network (NCCN) Guidelines indicate that for Stage I SCLC patients without mediastinal lymph node metastasis, lobectomy with mediastinal lymph node dissection followed by systemic therapy should be considered to offer a potential cure in clinical practice.[4, 5] However, surgery is associated with a high risk of cancer recurrence and postoperative morbidity. Postoperative complications after surgery for SCLC are both accompanied by higher short-term mortality and reduced long-term survival.[6] Relapse rates among patients following surgical resection are as high as $21-56 \%$.[7, 8] Thus, appropriate surgery candidate selection would contribute to a higher quality of life and improved morbidity, which are both of great clinical significance. Therefore, it is useful to build a clinically applicable and simple scoring system to select patients with a better prognosis to implement the surgery 
procedures. On the other hand, substantial heterogeneity exists among SCLC patients in terms of demographic and clinicopathological features, such as age, gender, pathological type, and tumor grade. Therefore, the prognosis of SCLC varied among different individuals. It is essential to stratify stage I SCLC into diverse prognostic categories to distinguish patients who can benefit the most from postoperative adjuvant therapies.

Nomograms, which create a visual manifestation of a statistical predictive model outputting a numerical probability of a clinical outcome, are commonly used to evaluate prognosis in cancer patients.[9] Nomograms provide guidance in clinical decision-making and add value for risk stratification, personalized treatment, and clinical trial design. A recent study has established a nomogram to predict the mortality of stage I SCLC patients.[10] The nomogram used data on patient characteristics and treatments extracted from the Surveillance, Epidemiology, and End Results (SEER) database. The study included three age groups, $18.9 \%$ of the patients aged $<60$ years, $54.2 \%$ aged $60-75$ years, and $26.9 \%$ aged $>75$ years. However, the nomogram had not undergone external validation, and a predictive model specifically for elderly patients diagnosed with stage I SCLC still needs to be constructed. In the current study, we attempted to construct and validate a nomogram to identify risk factors affecting cancer-specific survival (CSS) in elderly patients with Stage I SCLC based on data derived from the SEER database.

\section{Material And Methods}

\section{Data source}

All patient data were extracted from the National Cancer Institute $(\mathrm{NIH})$ SEER database using the SEER*stat software (version 8.3.5; http://seer.cancer.gov/seerstat/). The SEER database is sponsored by the $\mathrm{NIH}$ to collect information about cancer incidence and outcome. The database is updated annually and includes information on survival and follow-up.[11]

\section{Patient selection and data collection}

Tumor histology and site are coded in SEER according to the International Classification of Diseases (ICD) for Oncology Edition 3 (ICD-0-3).[12] Patients with ICD-0-3 histology code 8041/3-8045/3 of the lung and ICD-0-3 site code c34.0-c34.9 treated from 2004 to 2014 were identified. Demographic and clinicopathologic variables were documented for all patients studied. The variables included sex, age at diagnosis, race, laterality, primary site, tumor size, histologic types, the American Joint Committee on Cancer (AJCC) stage, survival data, and vital status. Because we narrowed our focus to surgery candidates first diagnosed with SCLC, not all treatment data were included in the study.

The patient inclusion criteria were (a) diagnosed as early-stage (AJCC stage I) SCLC; (b) at least 65 years of age at diagnosis; and (c) histologically confirmed malignancy. Exclusion criteria were (a) patients with missing data including unknown age of diagnosis; uncertain race; unknown tumor size; unknown cause of death; (b) survival was unknown or less than one month after diagnosis; and (c) patients with more than one primary cancer. 


\section{Endpoint Definition}

SCLC Cancer-specific death was defined as "patient death from SCLC as the underlying cause" in SEER. The endpoint of the present study was CSS, the period between the SCLC diagnosis and death due to cancer-specific death, with deaths from other causes censored. Follow-up was concluded on 31 December 2014.

\section{Construction and validation of the nomogram}

The included patients were divided into the training and validation cohorts randomly. The training cohort was applied to establish the nomogram. The Kaplan-Meier method was utilized to evaluate survival curves, and they were compared using the log-rank test. Variables with $p$-value $<0.05$ in univariate analysis were included in the multivariate analysis. The multivariate analysis was performed using the Cox proportional hazards regression model. The nomogram was constructed with potential risk factors ( $p$ $<0.05$ ) based on the multivariate Cox analysis.

The nomogram was subjected to bootstrap resampling 1,000 times for internal validation in the training set and external validation in the validation cohort. The nomogram's effectiveness was measured by the concordance index (C-index) and calibration plots. The C-index (ranges 0.5 to 1 ) was used to measure discrimination. A higher C-index value indicates a more accurate prognostic prediction.[13] The calibration

plots of the nomogram was used to assess the consistency between the actual and predicted survival outcomes.

\section{Statistical analysis}

Categorical variables were described as counts and percentages, while continuous variables were presented as medians and ranges. Statistical analyses to identify independent prognostic factors were conducted using SPSS 24.0 software. The package of $r m s$ in R software was used to construct the nomogram.[14]

\section{Results}

A total of 1,623 patients from the SEER database were identified and included in the study (Table 1). The median age was 74 years (ranged from 65 to 96 ), and 790 patients (48.8\%) were men. The majority, 1,444 (89\%), were Caucasian. The upper lobe was the most common SCLC site, 917 patients (56.5\%), followed by the lower lobe, 494 (30.4\%). The most frequent histologic type was "Small cell carcinoma, not otherwise specified (NOS)". The AJCC stage included $53.9 \%$ IA and $46.1 \%$ grade IB.

Table1. Patient characteristics and 1-, 3-, and 5-yr lung cancer-specific survival 


\begin{tabular}{|c|c|c|c|c|c|c|}
\hline & Characteristics & $\begin{array}{l}\text { Number } \\
\text { of } \\
\text { patients }\end{array}$ & $\begin{array}{l}\text { Months } \\
\text { of } \\
\text { survival } \\
\text { (median) } \\
\end{array}$ & $\begin{array}{c}\text { 1-year } \\
\text { cumulative } \\
\text { proportion of } \\
\text { CSS (CI) }\end{array}$ & $\begin{array}{c}\text { 3-year } \\
\text { cumulative } \\
\text { proportion of } \\
\text { CSS (CI) }\end{array}$ & $\begin{array}{c}\text { 5-year } \\
\text { cumulative } \\
\text { proportion of } \\
\text { CSS (CI) } \\
\end{array}$ \\
\hline & Total cases & 1623 & 34 & $\begin{array}{c}76.7 \%(74.5- \\
78.9 \%)\end{array}$ & $\begin{array}{c}48.1 \%(45.2- \\
51.0 \%)\end{array}$ & $\begin{array}{c}41.0 \%(37.9- \\
44.1 \%)\end{array}$ \\
\hline \multicolumn{7}{|l|}{ Gender } \\
\hline & Male & 790 & 62 & $\begin{array}{c}76.2 \%(73.1- \\
79.3 \%)\end{array}$ & $\begin{array}{c}45.9 \%(41.6- \\
50.2 \%)\end{array}$ & $\begin{array}{c}37.5 \%(32.8- \\
42.2 \%)\end{array}$ \\
\hline & Female & 833 & 58 & $\begin{array}{c}\text { 77.2\%(74.3- } \\
80.1 \%)\end{array}$ & $\begin{array}{c}50.0 \%(45.9- \\
54.1 \%)\end{array}$ & $\begin{array}{c}44.0 \%(39.7- \\
48.3 \%)\end{array}$ \\
\hline \multicolumn{7}{|l|}{ Age } \\
\hline & $65-69 y$ & 446 & 50 & $\begin{array}{c}83.6 \%(80.1- \\
87.1 \%)\end{array}$ & $\begin{array}{c}57.3 \%(52.0- \\
62.6 \%)\end{array}$ & $\begin{array}{c}48.8 \%(42.9- \\
54.7 \%)\end{array}$ \\
\hline & 70-74y & 446 & 39 & $\begin{array}{c}80.3 \%(76.4- \\
84.2 \%)\end{array}$ & $\begin{array}{c}51.4 \%(45.7- \\
57.1 \%)\end{array}$ & $\begin{array}{c}44.3 \%(37.5- \\
511 \%)\end{array}$ \\
\hline & 75-79y & 388 & 30 & $75.6 \%(71.0-$ & $44.1 \%(37.3-$ & $\begin{array}{l}36.6 \%(29.7- \\
435 \%)\end{array}$ \\
\hline & $\geq 80 y$ & 343 & 20 & $\begin{array}{c}64.3 \%(58.8- \\
69.8 \%)\end{array}$ & $\begin{array}{c}35.5 \%(29.2- \\
41.8 \%)\end{array}$ & $\begin{array}{c}29.3 \%(22.6- \\
36.0 \%)\end{array}$ \\
\hline \multicolumn{7}{|l|}{ Race } \\
\hline & White & 1444 & 34 & $\begin{array}{l}\text { 76.5\%(74.1- } \\
78.9 \%)\end{array}$ & $\begin{array}{c}48.0 \%(44.9- \\
51.1 \%)\end{array}$ & $\begin{array}{c}41.3 \%(38.0- \\
44.6 \%)\end{array}$ \\
\hline & Black & 120 & 45 & $\begin{array}{c}78.4 \%(70.8- \\
86.0 \%)\end{array}$ & $\begin{array}{c}53.1 \%(51.7- \\
54.5 \%)\end{array}$ & $\begin{array}{c}38.9 \%(26.9- \\
50.9 \%)\end{array}$ \\
\hline & $\begin{array}{l}\text { Asian or } \\
\text { Pacific } \\
\text { Islander }\end{array}$ & 59 & 29 & $\begin{array}{c}78.9 \%(67.7- \\
90.1 \%)\end{array}$ & $\begin{array}{c}37.0 \%(20.1- \\
53.9 \%)\end{array}$ & - \\
\hline \multicolumn{7}{|c|}{ Primary tumor site } \\
\hline & Main bronchus & 55 & 20 & $\begin{array}{c}58.4 \%(44.5- \\
72.3 \%)\end{array}$ & $\begin{array}{c}33.9 \%(17.2- \\
50.6 \%)\end{array}$ & - \\
\hline & $\begin{array}{l}\text { Upper lobe of } \\
\text { lung }\end{array}$ & 917 & 34 & $\begin{array}{c}78.5 \%(75.8- \\
81.2 \%)\end{array}$ & $\begin{array}{c}48.7 \%(44.8- \\
52.6 \%)\end{array}$ & $\begin{array}{c}42.5 \%(38.4- \\
46.6 \%)\end{array}$ \\
\hline & $\begin{array}{l}\text { Middle lobe of } \\
\text { lung }\end{array}$ & 116 & 31 & $\begin{array}{c}80.1 \%(72.3- \\
87.9 \%)\end{array}$ & $\begin{array}{c}63.0 \%(61.6- \\
64.4 \%)\end{array}$ & $\begin{array}{c}36.0 \%(21.5- \\
50.5 \%)\end{array}$ \\
\hline & $\begin{array}{l}\text { Lower lobe of } \\
\text { lung }\end{array}$ & 494 & 35 & $\begin{array}{c}\text { 76.5\%(72.6- } \\
80.4 \%)\end{array}$ & $\begin{array}{c}49.3 \%(43.3- \\
55.3 \%)\end{array}$ & $\begin{array}{c}40.1 \%(34.4- \\
45.8 \%)\end{array}$ \\
\hline & $\begin{array}{l}\text { Overlapping } \\
\text { lesion of lung }\end{array}$ & 5 & 107 & - & - & - \\
\hline & Lung, NOS & 36 & 12 & $\begin{array}{c}49.6 \%(32.1- \\
67.1 \%)\end{array}$ & $\begin{array}{c}28.8 \%(11.4- \\
46.2 \%)\end{array}$ & - \\
\hline \multicolumn{7}{|l|}{$\begin{array}{l}\text { Histologic } \\
\text { types }\end{array}$} \\
\hline & $\begin{array}{l}\text { Small cell } \\
\text { carcinoma, } \\
\text { NOS }\end{array}$ & 1429 & 33 & $\begin{array}{c}76.2 \%(73.8- \\
78.6 \%)\end{array}$ & $\begin{array}{c}46.9 \%(43.8- \\
50.0 \%)\end{array}$ & $\begin{array}{c}39.8 \%(36.5- \\
43.1 \%)\end{array}$ \\
\hline & $\begin{array}{l}\text { Oat cell } \\
\text { carcinoma }\end{array}$ & 46 & 14 & $\begin{array}{c}58.9 \%(44.2- \\
73.6 \%)\end{array}$ & $\begin{array}{c}25.0 \%(9.1- \\
40.9 \%)\end{array}$ & - \\
\hline & $\begin{array}{l}\text { Small cell } \\
\text { carcinoma, } \\
\text { fusiform cell }\end{array}$ & 4 & - & - & - & - \\
\hline & $\begin{array}{l}\text { Small cell } \\
\text { carcinoma, } \\
\text { intermediate } \\
\text { cell }\end{array}$ & 9 & 17 & $\begin{array}{c}71.4 \%(37.9- \\
104.9 \%)\end{array}$ & - & - \\
\hline & $\begin{array}{l}\text { Combined } \\
\text { small cell } \\
\text { carcinoma }\end{array}$ & 135 & 89 & $\begin{array}{c}\text { 88.1\%(82.4- } \\
93.8 \%)\end{array}$ & $\begin{array}{c}66.4 \%(57.2- \\
75.6 \%)\end{array}$ & $\begin{array}{c}59.0 \%(57.2- \\
60.8 \%)\end{array}$ \\
\hline \multicolumn{7}{|l|}{ Laterality } \\
\hline & Left & 711 & 34 & $\begin{array}{c}77.4 \%(74.1- \\
80.7 \%)\end{array}$ & $\begin{array}{c}48.6 \%(44.0- \\
53.2 \%)\end{array}$ & $\begin{array}{c}41.8 \%(37.1- \\
46.5 \%)\end{array}$ \\
\hline & Right & 912 & $\begin{array}{c}33 \\
\text { Page }\end{array}$ & 76.2\%(73.3- & 47.7\%(43.8- & $40.4 \%(36.1-$ \\
\hline
\end{tabular}


AJCC

stage

\begin{tabular}{cccccc} 
IA & 875 & 59 & $82.3 \%(79.6-$ & $56.8 \%(52.7-$ & $49.9 \%(45.3-$ \\
& & & $85.0 \%)$ & $60.9 \%)$ & $54.5 \%)$ \\
IB & \multirow{2}{*}{24} & $70.2 \%(66.7-$ & $38.2 \%(34.1-$ & $30.9 \%(26.6-$ \\
& & & $73.7 \%)$ & $42.3 \%)$ & $35.2 \%)$
\end{tabular}

Tumor

size

\begin{tabular}{lccccc}
$1-20 \mathrm{~mm}$ & 565 & 93 & $84.0 \%(80.9-$ & $60.2 \%(54.2-$ & $54.1 \%(48.6-$ \\
& & & $87.1 \%)$ & $66.2 \%)$ & $59.6 \%)$ \\
$21-50 \mathrm{~mm}$ & 839 & 30 & $75.4 \%(72.3-$ & $44.3 \%(40.2-$ & $37.0 \%(32.7-$ \\
& & & $78.5 \%)$ & $48.4 \%)$ & $41.3 \%)$ \\
$51-80 \mathrm{~mm}$ & 171 & 20 & $\begin{array}{c}66.2 \%(58.6- \\
73.0 \%)\end{array}$ & $\begin{array}{c}35.0 \%(26.4- \\
43.6 \%)\end{array}$ & $\begin{array}{c}26.5 \%(17.7- \\
35.3 \%)\end{array}$ \\
$>81 \mathrm{~mm}$ & 48 & \multirow{2}{*}{13} & $\begin{array}{c}51.0 \%(35.7- \\
66.3 \%)\end{array}$ & $\begin{array}{c}20.5 \%(6.6- \\
34.4 \%)\end{array}$ & - \\
\hline
\end{tabular}

Abbreviation: CSS, cancer-specific survival; CI, confidence interval; NOS, not otherwise specified; AJCC, American Joint Committee on Cancer;

The CSS curve is shown in Figure 1. The median CSS was 34 months (range, 1-143 months). The postoperative 1-, 3-, and 5-year CSS rates were 76.7\% (95\% Cl, 74.5\%-78.9\%), 48.1\% (95\% Cl, 45.2\% $51.0 \%)$ and $41.0 \%(95 \% \mathrm{Cl}, 37.9 \%-44.1 \%)$ respectively (Table 1$)$.

Independent prognostic factors and nomogram development

The clinicopathologic characteristics of lung cancer patients, the training set $(n=1,082)$ and validation set $(n=541)$, are listed in Table 2, respectively. In the training set, the univariate analysis demonstrated that age at diagnosis, primary site, histologic type, AJCC stage, and tumor size were associated with CSS (Table 3). All significant risk factors in the univariate analysis were included for the multivariate analysis. The results of the Cox hazards regression analyses are shown in Table 3. Analysis indicated that age at diagnosis, histologic types, AJCC stage, and tumor size remained significant independent risk factors in the Cox regression model. The Kaplan-Meier survival curve for significant risk factors is presented in Figure 2.

Table 2. Characteristics of the training and validation cohorts 


\begin{tabular}{|c|c|c|c|c|c|}
\hline \multirow[t]{2}{*}{ Characteristics } & & \multicolumn{2}{|c|}{$\begin{array}{l}\text { Training cohort } \\
(\mathrm{n}=1082)\end{array}$} & \multicolumn{2}{|c|}{$\begin{array}{c}\text { Validation cohort } \\
(\mathrm{n}=541)\end{array}$} \\
\hline & & $\mathrm{n}$ & $\%$ & $\mathrm{n}$ & $\%$ \\
\hline \multirow{3}{*}{$\begin{array}{l}\text { Age } \\
\text { Gender }\end{array}$} & Mean \pm SD(Range) & \multicolumn{2}{|c|}{$74.1 \pm 6.2(65-93)$} & \multicolumn{2}{|c|}{$74.1 \pm 6.3(65-96)$} \\
\hline & Male & 527 & $49 \%$ & 263 & $49 \%$ \\
\hline & Female & 555 & $51 \%$ & 278 & $51 \%$ \\
\hline \multicolumn{6}{|l|}{ Race } \\
\hline & White & 971 & $90 \%$ & 473 & $87 \%$ \\
\hline & Black & 72 & $6 \%$ & 48 & $9 \%$ \\
\hline & Asian or Pacific Islander & 39 & $4 \%$ & 20 & $4 \%$ \\
\hline \multicolumn{6}{|l|}{ Primary site } \\
\hline & Main bronchus & 42 & $4 \%$ & 13 & $2 \%$ \\
\hline & Upper lobe of lung & 603 & $56 \%$ & 314 & $58 \%$ \\
\hline & Middle lobe of lung & 75 & $7 \%$ & 41 & $8 \%$ \\
\hline & Lower lobe of lung & 335 & $31 \%$ & 159 & $29 \%$ \\
\hline & Overlapping lesion of lung & 1 & $0 \%$ & 4 & $1 \%$ \\
\hline & Lung, NOS & 26 & $2 \%$ & 10 & $2 \%$ \\
\hline \multicolumn{6}{|l|}{ Histologic types } \\
\hline & Small cell carcinoma, NOS & 955 & $88 \%$ & 474 & $88 \%$ \\
\hline & Oat cell carcinoma & 27 & $3 \%$ & 19 & $3 \%$ \\
\hline & $\begin{array}{l}\text { Small cell carcinoma, fusiform } \\
\text { cell }\end{array}$ & 4 & $0 \%$ & 0 & $0 \%$ \\
\hline & $\begin{array}{l}\text { Small cell carcinoma, } \\
\text { intermediate cell }\end{array}$ & 8 & $1 \%$ & 1 & $0 \%$ \\
\hline & Combined small cell carcinoma & 88 & $8 \%$ & 47 & $9 \%$ \\
\hline \multicolumn{6}{|l|}{ Laterality } \\
\hline & Left & 462 & $43 \%$ & 249 & $46 \%$ \\
\hline & Right & 620 & $57 \%$ & 292 & $54 \%$ \\
\hline \multicolumn{6}{|l|}{ AJCC stage } \\
\hline & IA & 586 & $54 \%$ & 289 & $53 \%$ \\
\hline & IB & 496 & $46 \%$ & 252 & $47 \%$ \\
\hline Tumor size & Mean \pm SD(Range) & $31.9=$ & $(1-400)$ & $31.6 \pm$ & $(5-150)$ \\
\hline $\begin{array}{l}\text { Survival } \\
\text { months }\end{array}$ & Mean $\pm \mathrm{SD}($ Range $)$ & $26.7=$ & $(1-143)$ & $26.5 \pm$ & $(1-134)$ \\
\hline
\end{tabular}

Abbreviation: SD, standard deviation; NOS, not otherwise specified; AJCC, American Joint Committee on Cancer;

Table 3. Univariate and multivariate Cox proportional hazards regression analyses for elderly patients with Stage I Small Cell Lung Cancer 


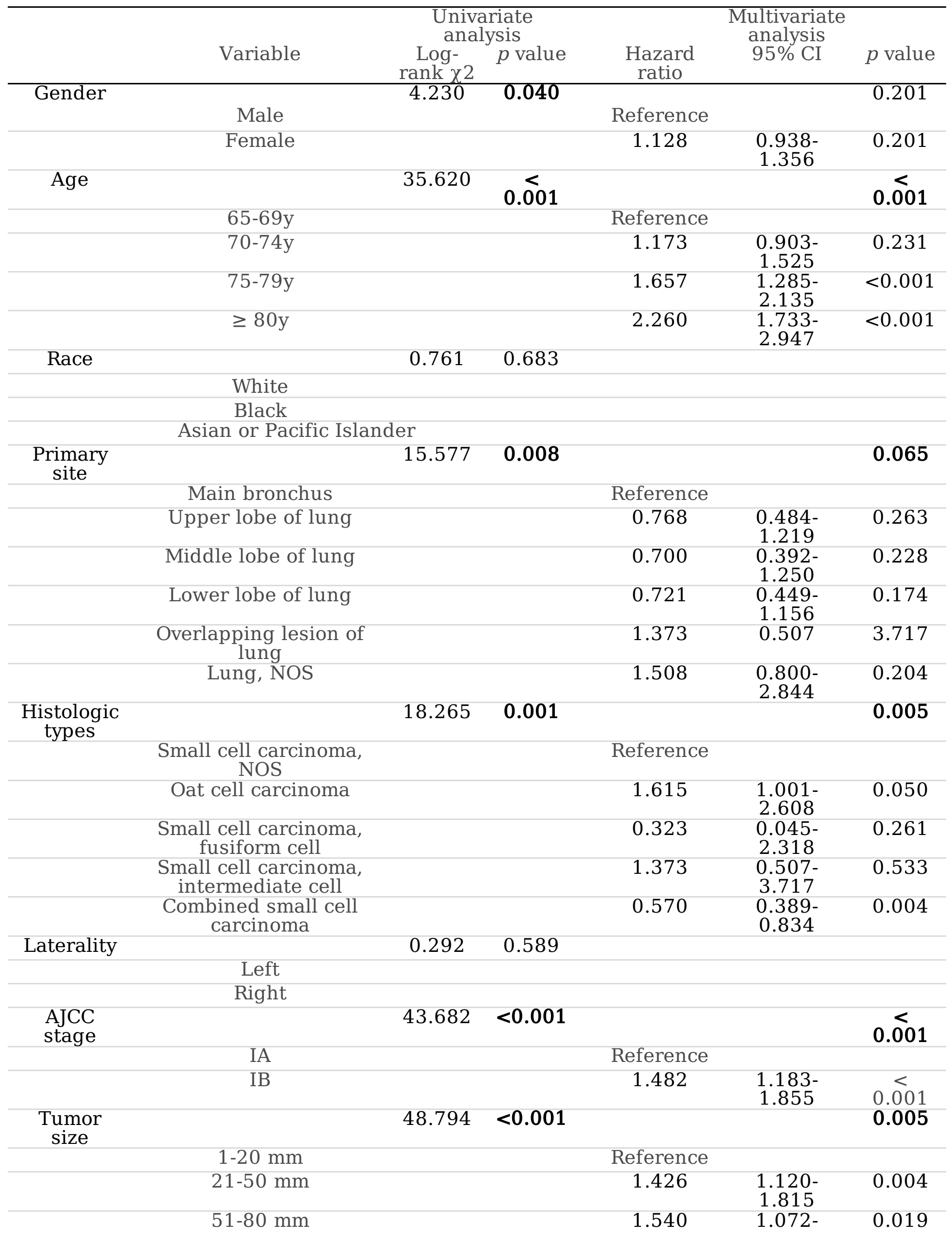


$\begin{array}{lll} & & 2.210 \\ & 21 \mathrm{~mm} & \\ & 2.208 & 3.620\end{array}$

0.002

Abbreviation: CI, confidence interval; NOS, not otherwise specified; AJCC, American Joint Committee on Cancer;

A nomogram containing the variables independently associated with CSS is presented in Figure 3 . The CSS rates of 1-, 3-, or 5-year can be calculated by

adding together the points corresponding to the patient's characteristics.

\section{Validation of the nomogram}

Internal validation of the nomogram was conducted by using internal bootstrap analyses with 1,000 resamplings. The $\mathrm{C}$-index of the prognostic nomogram for CSS prediction was $0.68(95 \% \mathrm{Cl}, 0.66-0.70)$. Similarly, external validation revealed that the C-index value for predicting CSS was $0.62(95 \% \mathrm{Cl}, 0.60-$ 0.64). These findings reflected the good discrimination ability of the model in both the training and validation cohorts. The internal and external calibration curves are shown in Figure 4. A diagonal gray line represents the actual CSS probability, and a solid black line represents the model's performance in forecasting the CSS probability. The two lines overlap closely, suggesting that the nomogram has reasonable estimations in both patient cohorts.

\section{Discussion}

This study established and validated a nomogram based on 1,623 elderly Stage I SCLC patients from the SEER database. The nomogram was used to predict the 1-, 3- and 5-year CSS rates of elderly patients with early-stage SCLC according to four significant factors: age at diagnosis, histologic type, AJCC stage, and tumor size. The nomogram is a reliable and straightforward predictive tool to estimate prognosis and make appropriate therapy recommendations.

As the population is aging and lung cancer affects many older people, efforts should be made, and additional resources should be given to choosing optimal treatments for this patient population. The current model contains only essential, clinically available variables. These variables are cheaper than molecular tests, a more economical and practical option. The C-index implied that the model is satisfactory, and the internal calibration curves show good consistency between the actual observation and nomogram prediction. Hence, the reliability and repeatability of the nomogram could be ensured.[15] The predictive ability of our nomogram is consistent compared to the previous study (C-index, 0.68 vs. Cindex, 0.68).[16] The predictive tool could identify high-risk patients, achieve more precise patient survival predictions, and prescribe the best treatment options.

A total of $30 \%$ of SCLC are defined as a limited-stage disease (characterized as disease confined to one hemithorax that can be compassed in a tolerable radiation field) or stage I-III based on the TNM classification.[17] Compared to extensive-stage disease (defined as disease beyond that included in the limited-stage disease), the 5 -year survival rate of limited-stage I SCLC is much higher (1.6\% vs. $12.1 \%)$. [18, 
19] Combs et al. indicated that the 5-year overall survival (OS) for stage I of resectable SCLC patients treated with surgery and chemotherapy even reached 49\%.[20] Both the American College of Chest Physicians (ACCP) and NCCN recommend surgery with adjuvant chemotherapy for stage I disease.[21, 22] $\mathrm{Li}$ and his colleagues recently constructed a nomogram for predicting CSS in patients diagnosed with stage I SCLC. Their results show that surgery, chemotherapy, and radiotherapy could improve the one-year survival rate. Surgery effectively reduces cancer-specific mortality, with the one-year cumulative incidence drops from $34.5 \%$ to $11.2 \%$.[10]

Overall, in clinical practice, the use of surgery and optimal treatment with chemotherapy in the elderly population remains low, leading to under-treatment and undesirable survival rates.[23, 24] Most elderly stage I SCLC patients are concerned about whether to undergo surgery, chemotherapy, and thoracic radiation, knowing the unwanted risk and side effects of these treatment options. Therefore, there is an urgent need to build a scoring system to guide patients. Besides, our study was aimed to assess the prognosis at the onset of diagnosis in the elderly SCLC patients. The nomogram helps select appropriate candidates for surgery, optimize the allocation of medical resources, and establish effective communication between patients and physicians.

By performing a comparison among four age cohorts (65-70 years, 70-75 years, 75-80 years, and $>80$ years), we found that the 5 -year CSS of the $>80$-years group was the lowest (29.3\% compared with $36.6 \%$, $44.3 \%, 48.8 \%$ ). Similar to previous studies, the current analysis confirms that age is an independent prognostic factor.[25-27] Similarly, a study of 1,303 patients enrolled in 11 trials show that older subjects, compared with younger subjects, have worse progression-free survival (PFS) and OS, increased comorbidity score, poor performance, and difficulty in tolerating and completing therapy. All these factors probably contribute to lower survival.[28] Older age is directly linked with an unfavorable prognosis, and this variable is recommended to be considered in selecting treatment strategies.[29]

The different histological types of SCLC are significantly associated with biological characteristics and prognosis. As shown in the nomogram, the histological type is an important predictive factor of CSS. From the data on the cumulative incidence of death, the combined SCLC has a smaller percentage of dying than other types of SCLC. Since 1981, the World Health Organization divided SCLC into three subtypes: oat cell, intermediate cell, and combined cell. Combined cell indicates combinations of malignant squamous and glandular elements.[30] Several retrospective studies have reported that combined SCLC has notable characteristic clinical features, frequently presenting with early-stage disease and potentially curable. This explains the possible benefit of multimodality therapies, including surgery, in patients with combined SCLC.[31, 32]

Growing studies reveal that tumor size is an independent prognostic factor of survival in many cancers, including SCLC.[33-35] According to our research, tumor size exerts a significant effect on the survival rate. In patients with tumor size $>2 \mathrm{~cm}$, CSS is significantly higher than in patients with a tumor size $\leq$ $2 \mathrm{~cm}$. Published research shows that tumor size is positively associated with the deficiency of patient's immune ability, which is related with cancer survival.[36, 37] Therefore, the positive relationship between immunity deficiency and tumor size might be why tumor size is a prognostic factor in SCLC. 
Our study has the following limitations: 1) potential inevitable bias due to the nature of retrospective data collection, 2) the SEER program lacks data on therapy and comorbidity, which may influence the prognosis, 3) the predictive nomogram was constructed according to data derived from the SEER database, which does not reflect the global population. Further, multi-center, large-sample studies are necessary to externally validate the nomogram to verify whether these results are generally applicable. Despite these limitations, the nomogram is constructed based on enormous population data collected in the SEER database leading to unique opportunities to forecast CSS for patients with Stage I SCLC.

\section{Conclusion}

Nomograms are constructed to estimate the probability of CSS of elderly patients with Stage I SCLC based on cohorts from the SEER database. Model validation proves its excellent performance, being highly accurate in predicting the prognosis of elderly patients with Stage I SCLC. The nomogram helps clinicians selecting individuals who can benefit the most from surgery, thus providing more individualized treatment strategies.

\section{List Of Abbreviations}

SCLC : small cell lung cancer; C-index, concordance index; CSS, cancer-specific survival; AJCC, American Joint Committee on Cancer; SEER, Surveillance, Epidemiology, and End Results; NCCN, National Comprehensive Cancer Network; ICD, International Classification of Diseases;

\section{Declarations}

\section{Ethics approval and consent to participate}

Our study did not require an ethical board approval because it did not contain human or animal trials.

\section{Consent for publication}

Not applicable.

\section{Availability of data and materials}

The datasets used and/or analyzed during the present study are available from the corresponding author upon reasonable request.

\section{Competing Interests}

The author(s) declared no potential conflicts of interest with respect to the research, authorship, and/or publication of this article.

\section{Funding}


This work was funded by the First Affiliated Hospital of Chongqing Medical University (Approval Number: PYJJ2019-09)

\section{Authors' contributions}

Conception and design: Shusen Sun, Jing Huang; Administrative support: Feng Xiong, Yin Xiao; Provision of study materials or patients: All authors; Collection and assembly of data: All authors; Data analysis and interpretation: All authors; Manuscript writing: Yaji Yang, Jing Huang; Final approval of manuscript: All authors.

\section{Acknowledgements}

None

\section{References}

1. Lunacsek OE, Ravelo A, Coutinho AD, Hazard SJ, Green MR, Willey J, Eaddy M, Goertz HP: First-Line Treatment with Bevacizumab and Platinum Doublet Combination in Non-Squamous Non-Small Cell Lung Cancer: A Retrospective Cohort Study in US Oncology Community Practices. Drugs Real World Outcomes 2016, 3:333-343.

2. Rudin CM, Ismaila N, Hann CL, Malhotra N, Movsas B, Norris K, Pietanza MC, Ramalingam SS, Turrisi AT, 3rd, Giaccone G: Treatment of Small-Cell Lung Cancer: American Society of Clinical Oncology Endorsement of the American College of Chest Physicians Guideline. J Clin Oncol 2015, 33:41064111.

3. Aberle DR, Adams AM, Berg CD, Black WC, Clapp JD, Fagerstrom RM, Gareen IF, Gatsonis C, Marcus PM, Sicks JD: Reduced lung-cancer mortality with low-dose computed tomographic screening. N Engl J Med 2011, 365:395-409.

4. Monirul Islam KM, Shostrom V, Kessinger A, Ganti AK: Outcomes following surgical treatment compared to radiation for stage I NSCLC: a SEER database analysis. Lung Cancer 2013, 82:90-94.

5. Ettinger DS, Aisner DL, Wood DE, Akerley W, Bauman J, Chang JY, Chirieac LR, D'Amico TA, Dilling TJ, Dobelbower M: NCCN guidelines insights: non-small cell lung cancer, version 5.2018. Journal of the National Comprehensive Cancer Network 2018, 16:807-821.

6. Nathan $\mathrm{H}$, Yin H, Wong SL: Postoperative Complications and Long-Term Survival After Complex Cancer Resection. Annals of Surgical Oncology 2017, 24:1-7.

7. Hou SZ, Cheng ZM, Wu YB, Sun Y, Liu B, Yuan MX, Wang XD: Evaluation of short-term and long-term efficacy of surgical and non-surgical treatment in patients with early-stage small cell lung cancer: $A$ comparative study. Cancer Biomark 2017, 19:249-256.

8. Stish BJ, Hallemeier CL, Olivier KR, Harmsen WS, Allen MS, Garces YI: Long-Term Outcomes and Patterns of Failure After Surgical Resection of Small-Cell Lung Cancer. Clinical Lung Cancer 2015, 16:e67-e73. 
9. lasonos A, Schrag D, Raj GV, Panageas KS: How to build and interpret a nomogram for cancer prognosis. Journal of Clinical Oncology 2008, 26:1364-1370.

10. Li J, Zheng Q, Zhao X, Zhao J, An T, Wu M, Wang Y, Zhuo M, Zhong J, Yang X: Nomogram model for predicting cause-specific mortality in patients with stage I small-cell lung cancer: a competing risk analysis. BMC cancer 2020, 20:1-10.

11. Warren JL, Klabunde CN, Deborah S, Bach PB, Riley GF: Overview of the SEER-Medicare data: content, research applications, and generalizability to the United States elderly population. Medical Care 2002, 40:3-18.

12. Fritz A, Percy C, Jack A, Shanmugaratnam K, Sobin L, Parkin DM, Whelan S: International classification of diseases for oncology. World Health Organization; 2000.

13. Fidel-David HM, Marinela C, O'Reilly EM, Austin D, Bolorsukh G, Saltz LL, Abou-Alfa GK: Advanced hepatocellular carcinoma: which staging systems best predict prognosis? Journal of Clinical Oncology 2010, 28:2889-2895.

14. Harrell Jr FE: rms: Regression Modeling Strategies. R package version 4.0-0. City 2013.

15. Balachandran VP, Gonen M, Smith JJ, DeMatteo RP: Nomograms in oncology: more than meets the eye. Lancet Oncology 2015, 16:e173-e180.

16. Pan H, Shi X, Xiao D, He J, Zhang Y, Liang W, Zhao Z, Guo Z, Zou X, Zhang J, He J: Nomogram prediction for the survival of the patients with small cell lung cancer. $J$ Thorac Dis 2017, 9:507-518.

17. Kalemkerian GP, Akerley W, Bogner P, Borghaei H, Chow LQ, Downey RJ, Gandhi L, Ganti AK, Govindan R, Grecula JC, et al: Small cell lung cancer. J Natl Compr Canc Netw 2013, 11:78-98.

18. J?Nne PA, Freidlin B, Saxman S, Johnson DH, Livingston RB, Shepherd FA, Johnson BE: Twenty-five years of clinical research for patients with limited-stage small cell lung carcinoma in North America : Meaningful improvements in survival. Cancer 2010, 95:1528-1538.

19. Chute JP, Chen T, Feigal E, Simon R, Johnson BE: Twenty years of phase III trials for patients with extensive-stage small-cell lung cancer: Perceptible progress. Journal of Clinical Oncology 1999, 17:1794-1801.

20. Combs SE, Hancock JG, Boffa DJ, Decker RH, Detterbeck FC, Kim AW: Bolstering the case for lobectomy in stages $\mathrm{I}$, II, and IIIA small-cell lung cancer using the National Cancer Data Base. $J$ Thorac Oncol 2015, 10:316-323.

21. Socinski MA, Evans T, Gettinger S, Hensing TA, Stinchcombe TE: Treatment of Stage IV Non-small Cell Lung Cancer Diagnosis and Management of Lung Cancer, 3rd ed: American College of Chest Physicians Evidence-Based Clinical Practice Guidelines. Chest 2013, 143:e341S-e368S.

22. Yu JB, Decker RH, Detterbeck FC, Wilson LD: Surveillance Epidemiology and End Results Evaluation of the Role of Surgery for Stage I Small Cell Lung Cancer. Journal of Thoracic Oncology 2010, 5:215219.

23. Jazieh AR, Kyasa MJ, Sethuraman G, Howington J: Disparities in surgical resection of early-stage non-small cell lung cancer. Journal of Thoracic \& Cardiovascular Surgery 2002, 123:1173-1176. 
24. Caprario LC, Kent DM, Strauss GM: Effects of chemotherapy on survival of elderly patients with smallcell lung cancer: analysis of the SEER-medicare database. J Thorac Oncol 2013, 8:1272-1281.

25. Deng J, Ren Z, Wen J, Wang B, Hou X, Xue Z, Chu X: Construction of a nomogram predicting the overall survival of patients with distantly metastatic non-small-cell lung cancer. Cancer Manag Res 2018, 10:6143-6156.

26. Gu C, Huang Z, Dai C, Wang Y, Ren Y, She Y, Su H, Chen C: Prognostic Analysis of Limited Resection Versus Lobectomy in Stage IA Small Cell Lung Cancer Patients Based on the Surveillance, Epidemiology, and End Results Registry Database. Front Genet 2018, 9:568.

27. Hsieh RK, Lim KH, Kuo HT, Tzen CY, Huang MJ: Female sex and bronchioloalveolar pathologic subtype predict EGFR mutations in non-small cell lung cancer. Chest 2005, 128:317-321.

28. Stinchcombe TE, Fan W, Schild SE, Vokes EE, Bogart J, Le QT, Thomas CR, Edelman MJ, Horn L, Komaki R, et al: A pooled analysis of individual patient data from National Clinical Trials Network clinical trials of concurrent chemoradiotherapy for limited-stage small cell lung cancer in elderly patients versus younger patients. Cancer 2019, 125:382-390.

29. Hurria A, Kris MG: Management of lung cancer in older adults. CA Cancer J Clin 2003, 53:325-341.

30. Nicholson SA, Beasley MB, Brambilla E, Hasleton PS, Colby TV, Sheppard MN, Falk R, Travis WD: Small cell lung carcinoma (SCLC): a clinicopathologic study of 100 cases with surgical specimens. American Journal of Surgical Pathology 2002, 26:1184-1197.

31. Babakoohi S, Fu P, Yang M, Linden PA, Dowlati A: Combined SCLC Clinical and Pathologic Characteristics. Clinical Lung Cancer 2013, 14:113-119.

32. Zhang C, Yang H, Zhao H, Lang B, Yu X, Xiao P, Zhang X: Clinical outcomes of surgically resected combined small cell lung cancer: a two-institutional experience. Journal of Thoracic Disease 2017, 9:151.

33. Claret L, Gupta M, Han K, Joshi A, Sarapa N, He J, Powell B, Bruno R: Evaluation of tumor-size response metrics to predict overall survival in Western and Chinese patients with first-line metastatic colorectal cancer. Journal of Clinical Oncology Official Journal of the American Society of Clinical Oncology 2013, 31:2110-2114.

34. Robinson B, Schlumberger M, Wirth LJ, Dutcus CE, Song J, Taylor MH, Kim SB, Krzyzanowska MK, Capdevila J, Sherman SI: Characterization of Tumor Size Changes Over Time From the Phase 3 Study of Lenvatinib in Thyroid Cancer. Journal of Clinical Endocrinology \& Metabolism 2016, 101:jc20153989.

35. Wang L, Dou X, Liu T, Lu W, Ma Y, Yang Y: Tumor size and lymph node metastasis are prognostic markers of small cell lung cancer in a Chinese population. Medicine (Baltimore) 2018, 97:e11712.

36. Osborne RH, Sali A, Aaronson NK, Elsworth GR, Mdzewski B, Sinclair AJ: Immune function and adjustment style: Do they predict survival in breast cancer? Psychooncology 2010, 13:199-210.

37. Strausberg RL: Tumor microenvironments, the immune system and cancer survival. Genome Biology 2005, 6:1-4. 
Figures

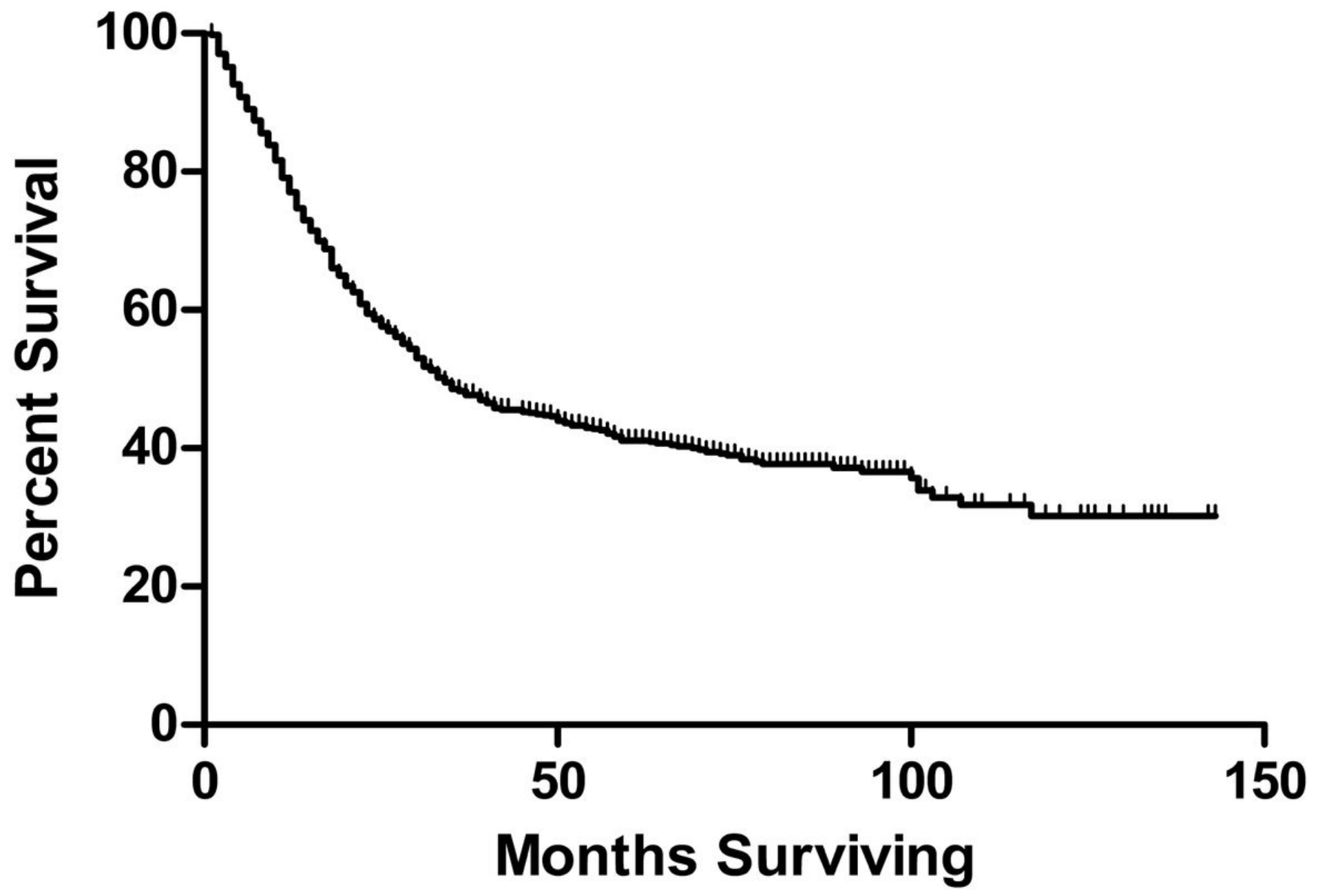

Figure 1

Kaplan-Meier survival curve of all included patients 
a

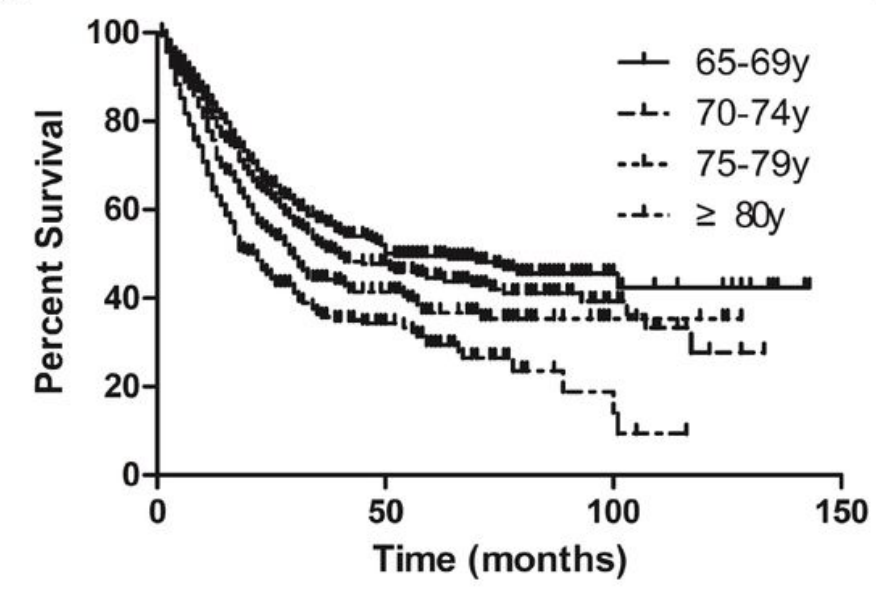

b

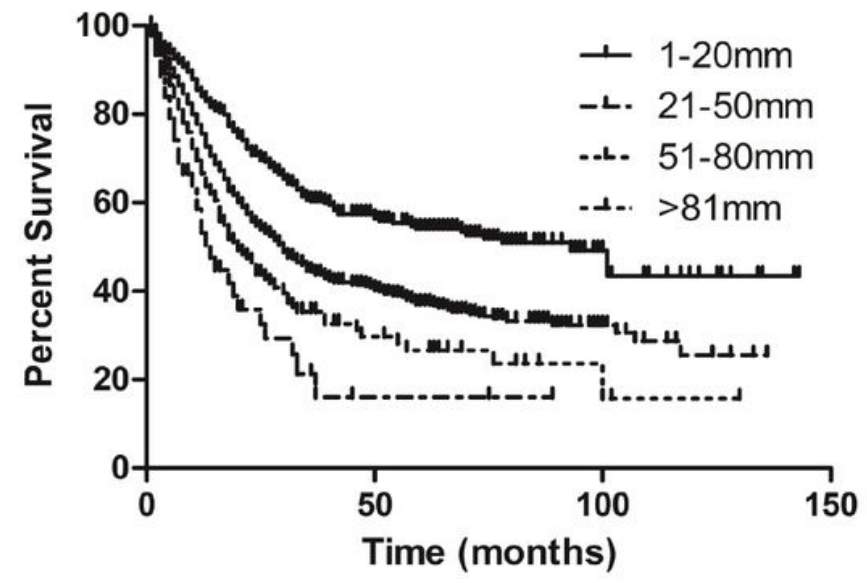

- Small cell carcinoma, NOS

-L. Oat cell carcinoma

.... Small cell carcinoma, fusiform cell
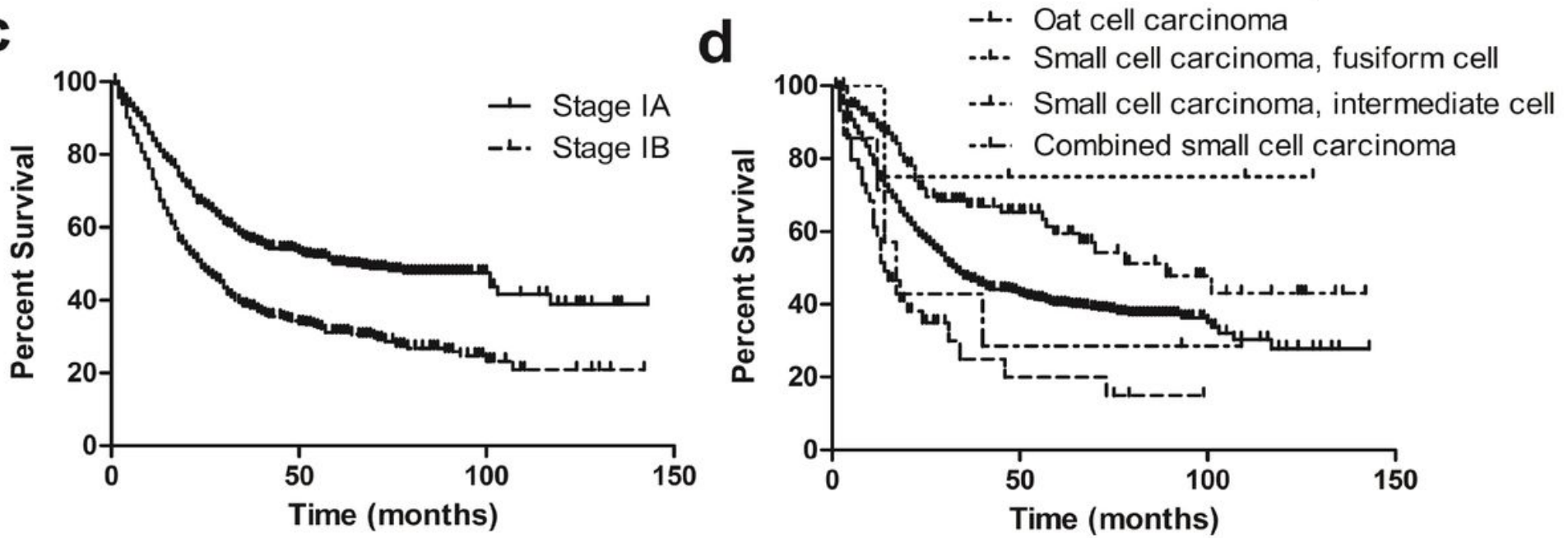

Figure 2

Kaplan-Meier survival curves for patients according to (a) Age, (b) Tumor size, (c) AJCC stage, (d) Histologic types 
Points

Age

Histology

AJCC stage

Tumor size

Total Points

1-year survival

3-year survival

5-year survival

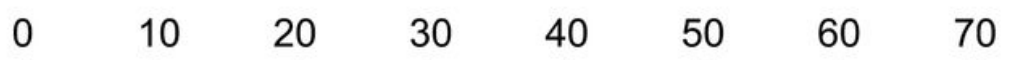

80

90 100
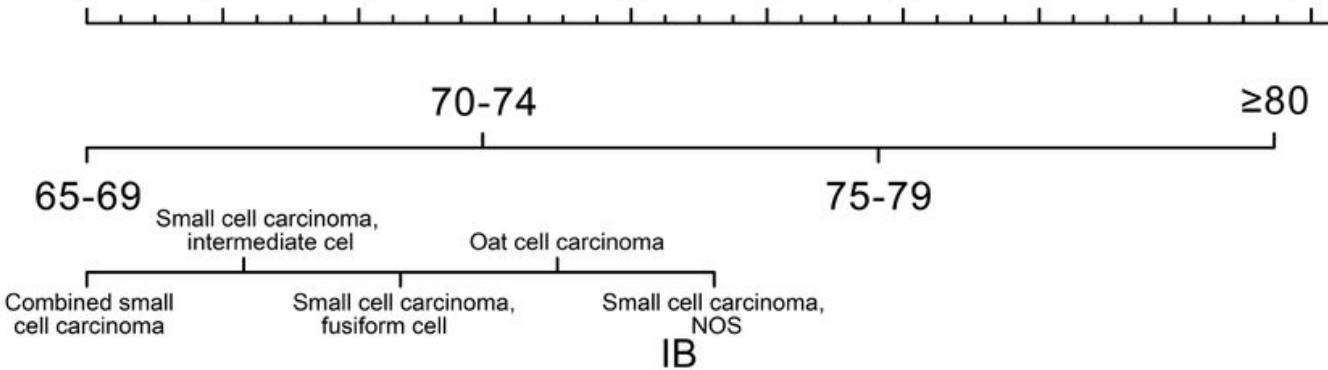

75-79

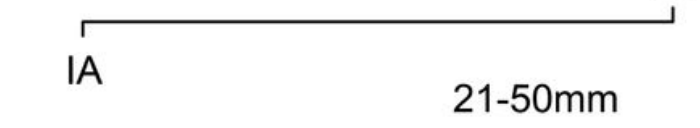

$>81 \mathrm{~mm}$
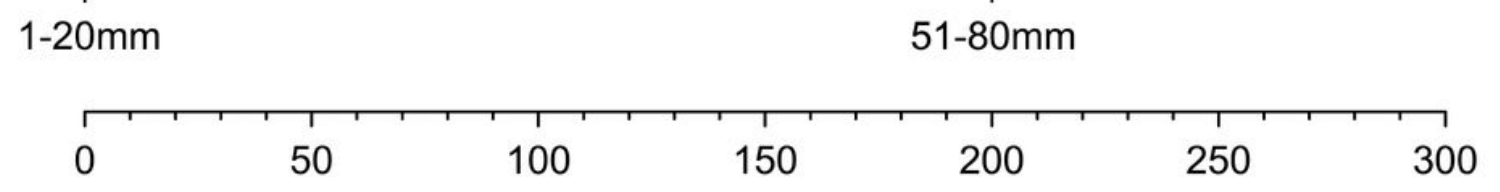

\begin{tabular}{llllll}
\hline 0.9 & 0.8 & 0.7 & 0.6 & 0.5 & 0.4
\end{tabular}
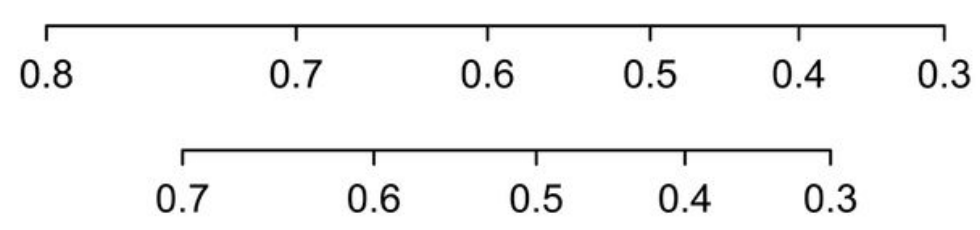

Figure 3

A nomogram for prediction of 1-, 3- and 5-year lung cancer-specific rates in elderly patients with Stage I Small Cell Lung cancer 

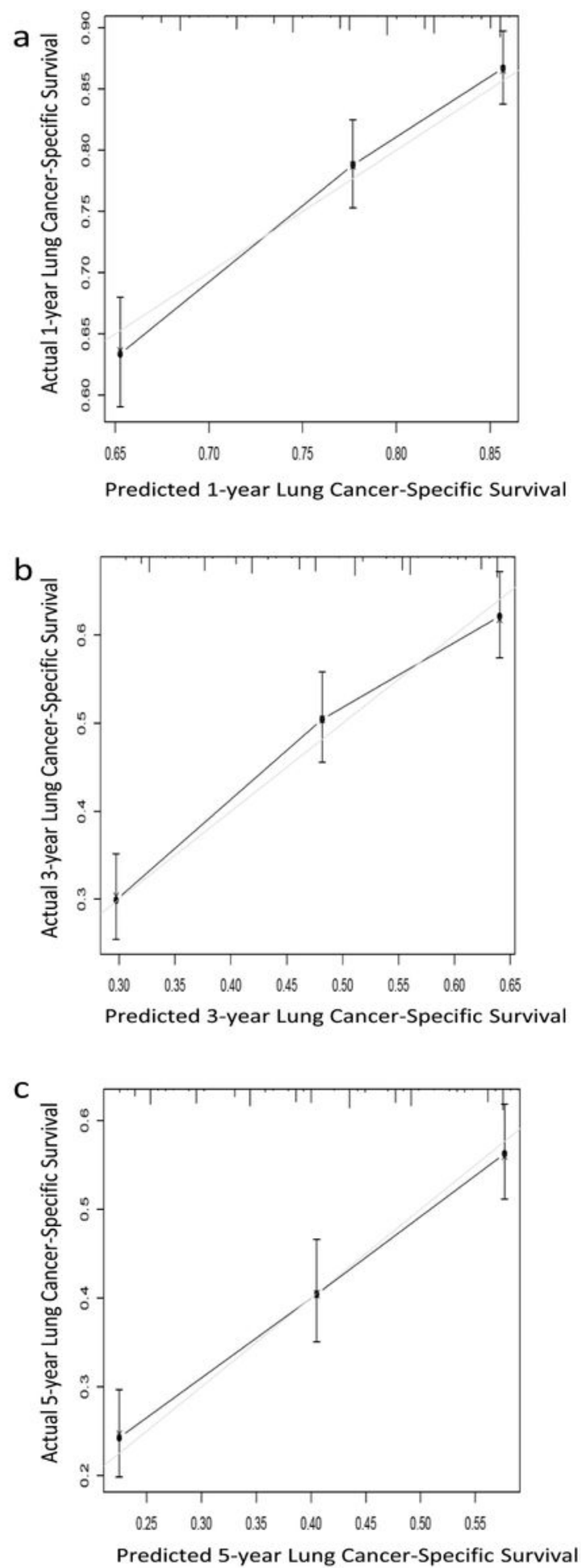

\section{Figure 4}

The calibration curves of 1-, 3- and 5-year lung cancer-specific survival rates of elderly patients with Stage I Small Cell Lung Cancer for training cohort $(a, b, c)$ and for validation cohort $(d, e, f)$ 